\title{
Paediatric Mortality: Aetiologies and Predictors among Children Aged 1 Month to 15 Years in a Tertiary Hospital in Douala, Cameroon
}

\author{
Daniele Kedy Koum 1,2,3* , Calixte Ida Penda1, Laurent Mireille Endale ${ }^{4,5}$, Henri Essome ${ }^{6,7}$, \\ Christiana Mpongo Moukongo' , Loick Pradel Kojom Foko ${ }^{8}$, Cecile Okalla Ebongue 9 , \\ Diomede Noukeu2 ${ }^{2}$, Dominique Enyama ${ }^{2}$, Charlotte Eposse ${ }^{1}$, Mbono Rhita1, \\ Patricia Epée Eboumbou1, Emile Telesphore Mboudou10, Paul Koki Ndombo11,12
}

\footnotetext{
${ }^{1}$ Department of Clinical Sciences, Faculty of Medicine and Pharmaceutical Sciences, University of Douala, Douala, Cameroon

${ }^{2}$ Department of Pediatrics, Douala Gynaeco-Obstetric and Pediatric Hospital, Douala, Cameroon

${ }^{3}$ Deido District Hospital, Douala, Cameroon

${ }^{4}$ Department of Internal Medicine, Faculty of Health Sciences, University of Buea, Buea, Cameroon

${ }^{5}$ Department of Internal Medicine, Laquintinie Hospital, Douala, Cameroon

${ }^{6}$ Department of Surgery, Faculty of Medicine and Pharmaceutical Sciences, The University of Douala, Douala, Cameroon

${ }^{7}$ Department of Gynecology, Laquintinie Hospital, Douala, Cameroon

${ }^{8}$ Department of Animal Organism Biology, Faculty of Science, The University of Douala, Douala, Cameroon

${ }^{9}$ Department of Biology, Faculty of Medicine and Pharmaceutical Sciences, The University of Douala, Douala, Cameroon

${ }^{10}$ Department of Gynecology, Douala Gynaeco-Obstetric and Pediatric Hospital, Douala, Cameroon

${ }^{11}$ Department of Pediatrics, Faculty of Medicine and Biomedical Sciences, University of Yaounde I, Yaoundé, Cameroon

${ }^{12}$ Chantal Biya Foundation, Mother-Child Centre, Yaoundé, Cameroon

Email: *dckedykoum @yahoo.fr
}

How to cite this paper: Kedy Koum, D., Penda, C.I., Endale, L.M., Essome, H., Moukongo, C.M., Kojom Foko, L.P., Okalla Ebongue, C., Noukeu, D., Enyama, D., Eposse, C., Rhita, M., Eboumbou, P.E., Mboudou, E.T. and Koki Ndombo, P. (2021) Paediatric Mortality: Aetiologies and Predictors among Children Aged 1 Month to 15 Years in a Tertiary Hospital in Douala, Cameroon. Open Journal of Pediatrics, 11, 360-378.

https://doi.org/10.4236/ojped.2021.113033

Received: June 13, 2021

Accepted: July 24, 2021

Published: July 27, 2021

\begin{abstract}
Background: Children and adolescent mortality remains a public health concern in developing countries. This study aimed to describe risk factors and aetiologies of mortality among children and young adolescents at a tertiary hospital in the town of Douala, Cameroon. Methods: We carried out a retrospective cohort study from January $1^{\text {st }}$ to May $31^{\text {st }}, 2019$ among deceased patients aged 1 month to 15 years admitted to the paediatric ward of the Gynaeco-Obstetric and Paediatric Hospital. Data of interest were collected and analysed. Results: Out of 3088 children admitted, 123 death cases were recorded. The overall hospital mortality rate was $3.98 \%$. Females accounted for $51 \%$ of the deceased patients. Fever was the main reason for consultation. Severe malaria was the most common diagnosis. In univariate logistic regression analysis, factors associated with mortality included hyperthermia $(\mathrm{OR}=$ 0.24 ; $95 \%$ CI $0.80-1.33 ; p=0.012)$, coma/impaired consciousness $(\mathrm{OR}=$ 0.30 ; 95\% CI $0.10-0.88$; $p=0.029$ ), pneumonia (OR $=3.95$; 95\% CI 1.42 -
\end{abstract}


Copyright $\odot 2021$ by author(s) and Scientific Research Publishing Inc. This work is licensed under the Creative Commons Attribution International License (CC BY 4.0).

http://creativecommons.org/licenses/by/4.0/ (c) (i) Open Access
$10.97 ; p=0.008)$, antipyretic therapy ( OR $=0.28 ; 95 \%$ CI $0.11-0.73 ; p=$ 0.009 ), and no medication ( $\mathrm{OR}=4.50 ; 95 \% \mathrm{CI} 1.05-9.29 ; p=0.043)$. In multivariate regression analysis, coma/impaired consciousness was found to be the only factor associated with mortality $(\mathrm{OR}=6.24 ; 95 \%$ CI $1.15-33.73 ; p=$ 0.034). Conclusion: The present study reveals that most of death cases were due to preventable causes, especially infectious diseases. Efficient reduction in children and adolescent mortality could be achieved by adequately addressing these causes.

\section{Keywords}

Children, Young Adolescents, Mortality, Aetiologies, Risk Factors, Cameroon

\section{Introduction}

Mortality rate is defined as the number of annual deaths relative to the number of inhabitants in a given population [1]. Despite progress made over these last three decades, millions of newborns, children and young adolescents die every year worldwide, mostly due to preventable or treatable causes including infectious diseases and injuries [1]. These deaths largely occurred in developing countries, and are often a reflection of the limited access to basic health interventions such as clean water and sanitation, vaccination, medical treatment, and adequate nutrition [1]. In this context, mortality rates in infants, children and young adolescents are not only key indicators for appraising their well-being, but also more broadly, a surrogate for evaluating level of sustainable social and economic development [2].

According to the World Health Organisation (WHO), the global child mortality rate decreased from 85 to 67 deaths per 1000 live births (LB) between 1990 and 2000. Prevention and reduction of infant-juvenile and young adolescent mortality by two thirds by 2015 was one of the objectives of the Millennium Development Goals. In this regard, many efforts have been made by international and scientific community through development, implementation and scale up of several health interventions. As a consequence, an improvement in survival rates in the above mentioned social groups was noted all around the world [3]-[9].

In Africa, the average child mortality rate is 150 deaths per $1000 \mathrm{LB}$, which is 8 times higher than those seen in European countries. In Nigeria, estimated mortality rate in children aged $<5$ years old is 183 deaths per $1000 \mathrm{LB}$. In resource-constrained countries, reporting of morbidity and mortality health statistics are mainly based on hospital records, given the constraints related to the implementation of community-based investigations [10] [11].

While concerted efforts aimed at improving child survival have led to large reductions in mortality levels among children and young adolescents, persistent and intolerably high numbers of deaths emphasise the need for continuous efforts to reduce mortality in these age groups [12]. The international community 
recognizes the crucial need to end preventable child deaths, making it an essential part of the Global Strategy for Women's, Children's, and Adolescent's Health (2016-2030), and the third Sustainable Development Goal (SDG) to ensure healthy lives and promote wellbeing for all people at all ages [12] [13] [14].

Moreover, the risk of death for children aged 5 - 15 years old may be lower than those in younger children. However, preventable death causes such as infectious diseases, drowning, and road injuries are also highly prevalent in children aged 5 - 15 years old. Given the crucial role of education, as well as the associated broader social implications during this important stage of life, the survival and well-being of children and adolescents, and later during their adulthood, should not be ignored [13] [14].

Paediatric mortality is a major public health problem in developing countries, especially in Cameroon. The mortality rate in children under 5 years decreased from $150.7 \%$ o to $144 \%$, and this is far from the national objectives of $75.8 \%$ o [15]. The present study was designed to provide a comprehensive description of risk factors and aetiologies of death among children aged 5 - 15 years old attending a premium hospital in the town of Douala, Cameroon, where such data are greatly needed. This study will help improve case management and reduce mortality at this level of the health pyramid care.

\section{Methods}

\subsection{Study Design and Setting}

A retrospective cohort study was conducted at the paediatric ward of Douala Gynaeco-Obstetric and paediatric Hospital (DGOPH), a tertiary health facility located in town of Douala, Cameroon. The study was conducted for five months from January $1^{\text {st }}$ to May $31^{\text {st }}, 2019$. The paediatric ward of DGOPH is open for 24 hours a day, from Monday to Sunday. It consists of three units namely 1) the general paediatrics unit, 2) the neonatology unit, and 3) the external consultation unit. The staff of the paediatric ward includes five paediatricians (05), five general practitioners (05), nineteen nurses (19), and five caregivers (05).

Children in distress are managed at the emergency room of the general paediatric unit, and then are transferred to hospitalization rooms after their stabilization. Four beds are present in the emergency room in which three staff members (one medical doctor and two nurses) work permanently. Each bed is equipped with a multi-parameter monitor and oxygen therapy device. The hospital has a medical biology laboratory, video electroencephalography (video-EEG), and medical imaging service with a computed tomodensitometry module.

\subsection{Study Population}

Medical records of deceased children aged 1 month to 15 years old of both sexes were included in the study. Medical records with no admission date, date of death, medical observation, and poorly reported hospital evolution data were excluded from the study. A minimum sample size of 44 individuals was required 
for the study based on the Lorentz's formula and data on children's mortality rate $(2.95 \%)$ from the same region [15] where our study was conducted.

\subsection{Data Collection}

A questionnaire form was used to collect data of interest from patients' medical records. These data included sociodemographic characteristics and past history of the deceased children (age, gender, origin, residence, and immunisation status), clinical data (reasons for consultation, date and month of admission, date of death, the delay from admission to death, diagnosis at entrance based on clinical features and laboratory, radiological and electrophysiological analyses, intra-hospital complications, treatment, aetiologies of death), and risk factors of death.

\subsection{Definition of Terms}

- Hypothermia: body temperature less than $36.5^{\circ} \mathrm{C}$.

- Hyperthermia: body temperature $\geq 38^{\circ} \mathrm{C}$.

- Hypotension: a blood pressure $(\mathrm{mmHg}) \leq 80-105 / 55-70$ in toddlers, $\leq$ 90-105/60-70 in infants, $\leq 95-119 / 60-76$ in children, and $\leq 110-124 / 70-80$ in teenagers.

- Hypertension: a blood pressure $(\mathrm{mmHg}) \geq 80-105 / 55-70$ in toddler, $\geq$ 90-1050/60-70 in infant, $\geq 95-119 / 60-70$ in children, and $\geq 110-124 / 70-80$ in teenager.

- Tachycardia: a pulse $\geq 120$ in toddler, $\geq 115$ in infant, $\geq 110$ in children, and $\geq 100$ in teenagers.

- Bradycardia: a pulse $\leq 80$ in toddler, $\leq 75$ in infant, $\leq 70$ in children, and $\leq 60$ in teenager.

- Bradypnea: respiratory rate $\leq 30$ in toddler, $\leq 24$ in infants, $\leq 22$ in children, and $\leq 18$ in teenager.

- Polypnea: respiratory rate $\geq 60$ in toddler, $\geq 40$ in infant; $\geq 35$ in children, and $\geq 30$ in teenager.

- Coma: Glasgow coma scale; Stage I $=\leq 4$, Stage II $=5$ - 7, Stage III $=8-10$, Stage IV $=11-14$ and for the Blantyre score; Stage I $=4$, Stage II $=3-2$, Stage II $=1$, Stage IV $=0$.

- Anaemia: haemoglobin level $<12 \mathrm{~g} / \mathrm{dL}$, and which was further classified into mild $(10-11 \mathrm{~g} / \mathrm{dL})$, moderate $(8-9 \mathrm{~g} / \mathrm{dL})$, and severe $(\leq 7 \mathrm{~g} / \mathrm{dL})$.

- Circumstances of death were the aetiologies of death found in the medical records.

\subsection{Statistical Analysis}

Data were keyed into an Excel 2016 spreadsheet, and then exported to the statistical package for social sciences (SPSS) v20 for Windows (SPSS, IBM, Inc., Chicago, IL, USA) and GraphPad v5.03 for Windows (GraphPad PRISM, San Diego, CA, USA). Qualitative and quantitative variables were presented as percentages 
and mean \pm standard deviation, respectively. Pearson chi square test was used to compared proportions while univariate and multivariate logistic regression analyses were used to identify risk factors of mortality. Odd ratio (OR) and their confidence interval at 95\% (95\% CI) were computed to measure the strength of association between independent variables and dependent variable (i.e., mortality rate). The different independent variables tested in logistic analysis were sociodemographic (age, gender and origin), reasons for consultation, vital parameters (temperature, pulse, respiration rate, $\mathrm{SaO}_{2}$ ), neurological status (Glasgow and Blantyre findings), biological parameters ( $C$ reactive protein, transaminases, urea, creatine and blood count), diagnosis on admission, hospital complications, and treatment administered. Only independent variables for which $p$-value was $\leq 0.20$ in univariate logistic model were included in the multivariate logistic model. Statistical significance was set at $p$-value $<0.05$.

\subsection{Ethical Considerations}

This study has received the approval of the ethics committee of the University of Douala ( $N^{\circ}$ 2019/0014/HGOPED/DG/CEI). Administrative approval was obtained from The Director of the DGOPH. The information obtained from the deceased children records were used according to the strict respect of confidentiality.

\section{Results}

A total of 3088 patients were admitted at the paediatric ward of the DGOPH during the study period. One hundred and twenty-three were eligible for the study, 23 of them were excluded from the study as per the above mentioned exclusion criteria. Finally, 100 patients were eligible for the study as depicted in Figure 1.

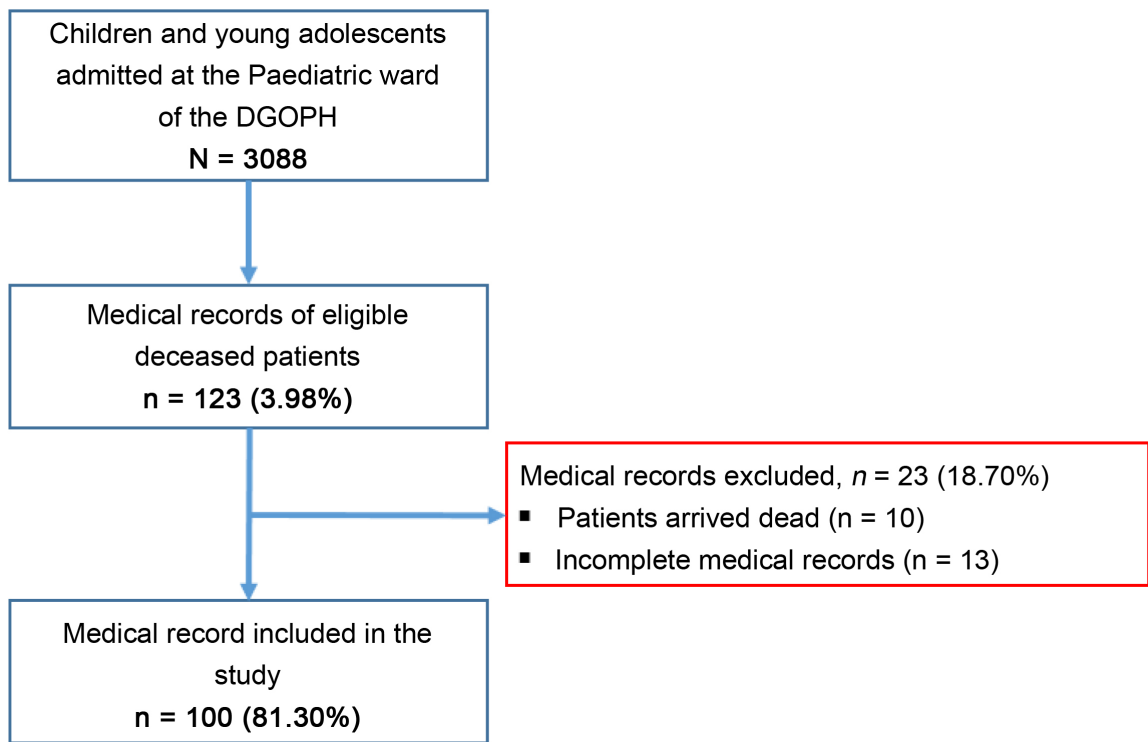

Figure 1. Flow diagram depicting the inclusion of patients' medical records. 


\subsection{Year-Wise Mortality Trend and Sociodemographic Characteristics}

The evolution of mortality rate from September $1^{\text {st }} 2015$ to April $31^{\text {st }} 2019$ is presented in Figure 2. The number of deaths was highest during the year 2018 while no death case was recorded in 2015. Besides, mortality rate before 24 hours was higher than those reported after 24 hours irrespective of the year (Figure 2).

A total of 100 patients were included in the study. Half of them were aged 6 12 years, with a mean age of $6 \pm 3$ years old. Female accounted for $51 \%$ of the patients (Table 1). Most of the patients were referred to the DGOPH (66.0\%), were coming from popular areas (62.0\%), and had updated immunization status (77.0\%) (Table 1).

\subsection{Reasons for Consultation}

A large number of reasons for hospital consultation were recorded in this study. Fever (64.0\%), respiratory distress (44.0\%), fatigue (31.0\%), convulsions (29.0\%), and coma/impaired consciousness (29.0\%) were the main reasons (Table 2).

\subsection{Vital Parameters, Neurological Status and Diagnosis on Admission}

On admission, most of the children presented with hyperthermia (72.2\%), Polypnea (85.5\%) and tachycardia (82.1\%) (Table 3). Based on the Blantyre score, $44.6 \%$ and $19.6 \%$ of the patients had level of consciousness graded stage II and III, respectively. Besides, the main causes of diagnosis on admission included severe malaria (42.0\%), pneumonia (27.0\%), severe dehydration (16.0\%), and septic shock (16.0\%) (Figure 3).

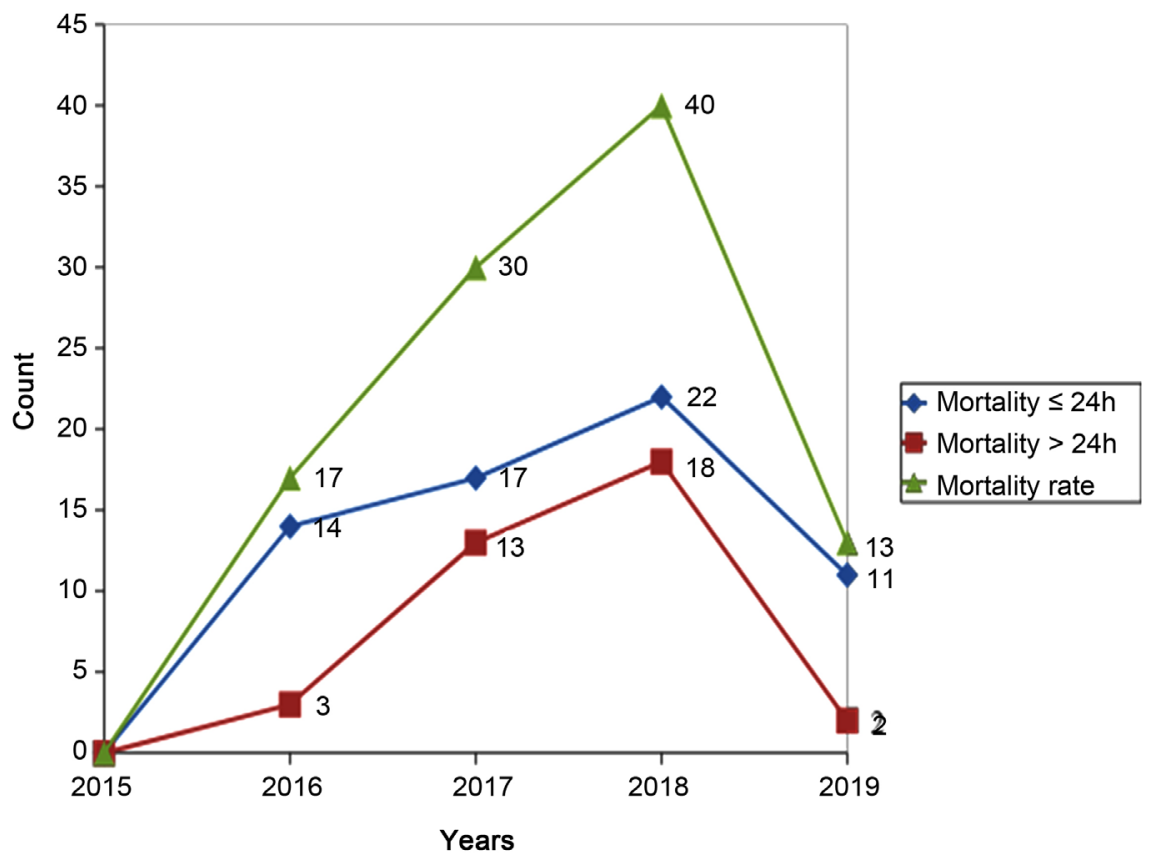

Figure 2. Evolution of paediatric mortality between 2015 and 2019. 


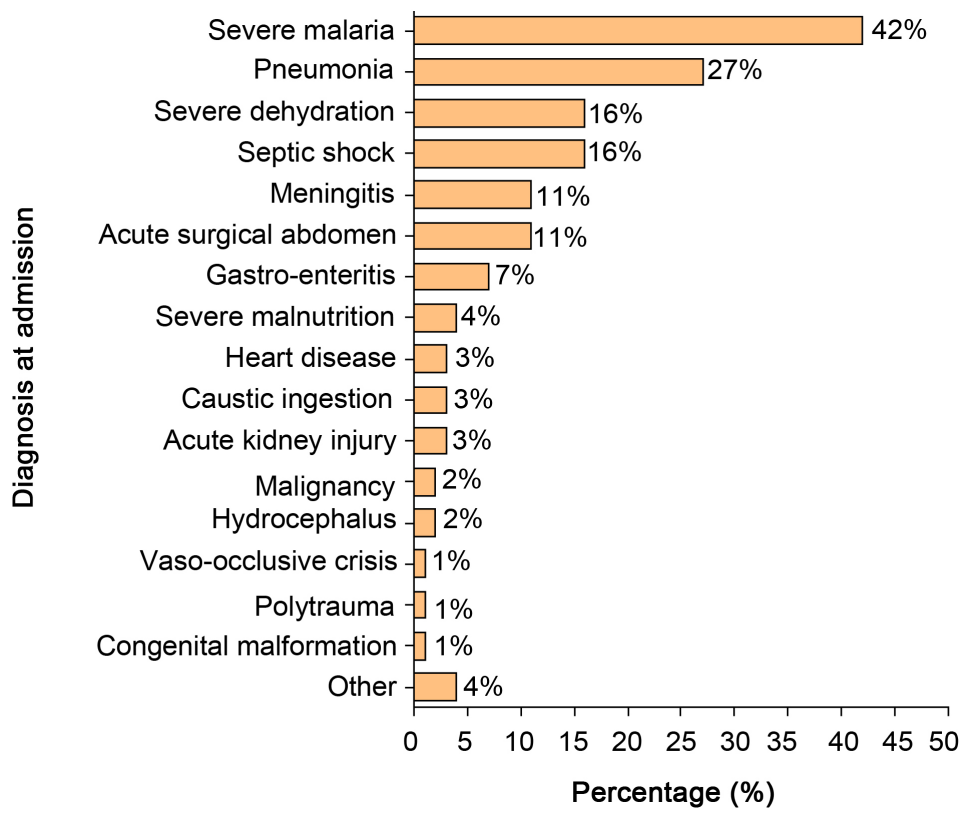

Figure 3. Diagnosis on admission.

Table 1. Sociodemographic characteristics and past history of the deceased children.

\begin{tabular}{|c|c|c|c|}
\hline Variables & Categories & $\begin{array}{c}\text { Frequency } \\
n=100\end{array}$ & $\begin{array}{c}\text { Percentage } \\
(\%)\end{array}$ \\
\hline \multirow{4}{*}{ Age } & 1 month -2 years & 15 & 15.0 \\
\hline & 3 years -5 years & 31 & 31.0 \\
\hline & 6 years -12 years & 50 & 50.0 \\
\hline & 13 years - 15 years & 4 & 4.0 \\
\hline \multirow{3}{*}{ Gender } & Female & 51 & 51.0 \\
\hline & Male & 49 & 49.0 \\
\hline & Female to male ratio & 1.04 & \\
\hline \multirow{2}{*}{ Origin } & Home & 34 & 34.0 \\
\hline & Referred & 66 & 66.0 \\
\hline \multirow{3}{*}{ Residence } & Popular area & 62 & 62.0 \\
\hline & Residential area & 32 & 32.0 \\
\hline & Not specified & 6 & 0.6 \\
\hline \multirow{3}{*}{ Immunization } & Outdated & 3 & 0.3 \\
\hline & Updated & 77 & 77.0 \\
\hline & Not specified & 20 & 20.0 \\
\hline \multirow{6}{*}{$\begin{array}{l}\text { No } \\
\text { immunization }\end{array}$} & Outdated & 20 & 20.0 \\
\hline & Updated & 2 & 2.0 \\
\hline & Human immunodeficiency infection & 1 & 1.0 \\
\hline & Sickle cell disease & 1 & 1.0 \\
\hline & Haemophilia & 1 & 1.0 \\
\hline & Others & 7 & 7.0 \\
\hline
\end{tabular}


Table 2. Reasons for consultation.

\begin{tabular}{lcc}
\hline \multicolumn{1}{c}{ Reasons for consultation } & $\begin{array}{c}\text { Frequency } \\
\boldsymbol{n}=\mathbf{1 0 0}\end{array}$ & $\begin{array}{c}\text { Percentage } \\
(\%)\end{array}$ \\
\hline Fever & 64 & 64.0 \\
Respiratory distress & 44 & 44.0 \\
Fatigue & 31 & 31.0 \\
Convulsion & 29 & 29.0 \\
Coma/Impaired consciousness & 29 & 29.0 \\
Pallor & 22 & 22.0 \\
Diarrhoea & 18 & 18.0 \\
Cough & 15 & 15.0 \\
Vomiting & 13 & 13.0 \\
Abdominal pain & 11 & 11.0 \\
Emaciation & 9 & 26.5 \\
Rectorragia & 6 & 17.6 \\
Others & 5 & 14.7 \\
Trauma & 1 & 3.0 \\
Constipation & 1 & 1.0 \\
Headache & 3 & 1.0 \\
Chest pain & 1 & 1.0 \\
Oedema & 3.8 \\
Hematemesis & 1 & 1.0 \\
\hline
\end{tabular}

The sum of percentage exceeds $100 \%$ as a patient could have more than one reason.

\subsection{Aetiologies of Deaths}

As depicted in Figure 4, eight causes were identified as responsible for deaths of patients. The main death aetiology was decompensated septic shock $(32.0 \%)$. It should be noted that more than one third of deaths were due to aetiologies of unknown origin (Figure 4).

\subsection{Factors Associated with Mortality}

In the univariate logistic regression analysis, a total of six factors were found to be statistically associated with mortality, and these included coma/impaired consciousness; elevated temperature, abnormal level of $\mathrm{C}$ reactive protein, pneumonia, absence of medication, and the administration of antipyretic therapy. The risk of death was about five times (OR $=4.50,95 \%$ CI $1.05-9.29, p=$ 0.043) higher in patients having received no medication compared to their counterparts under therapy. Only the presence of coma/impaired consciousness factor was significantly associated with mortality in the multivariate logistic regression analysis. Patients diagnosed with coma/impaired consciousness had a six times higher mortality risk as compared to those with normal consciousness $(\mathrm{OR}=6.24,95 \%$ CI $1.15-33.73, p=0.034)($ Table 4$)$. 
Table 3. Vital parameters and neurological status on admission.

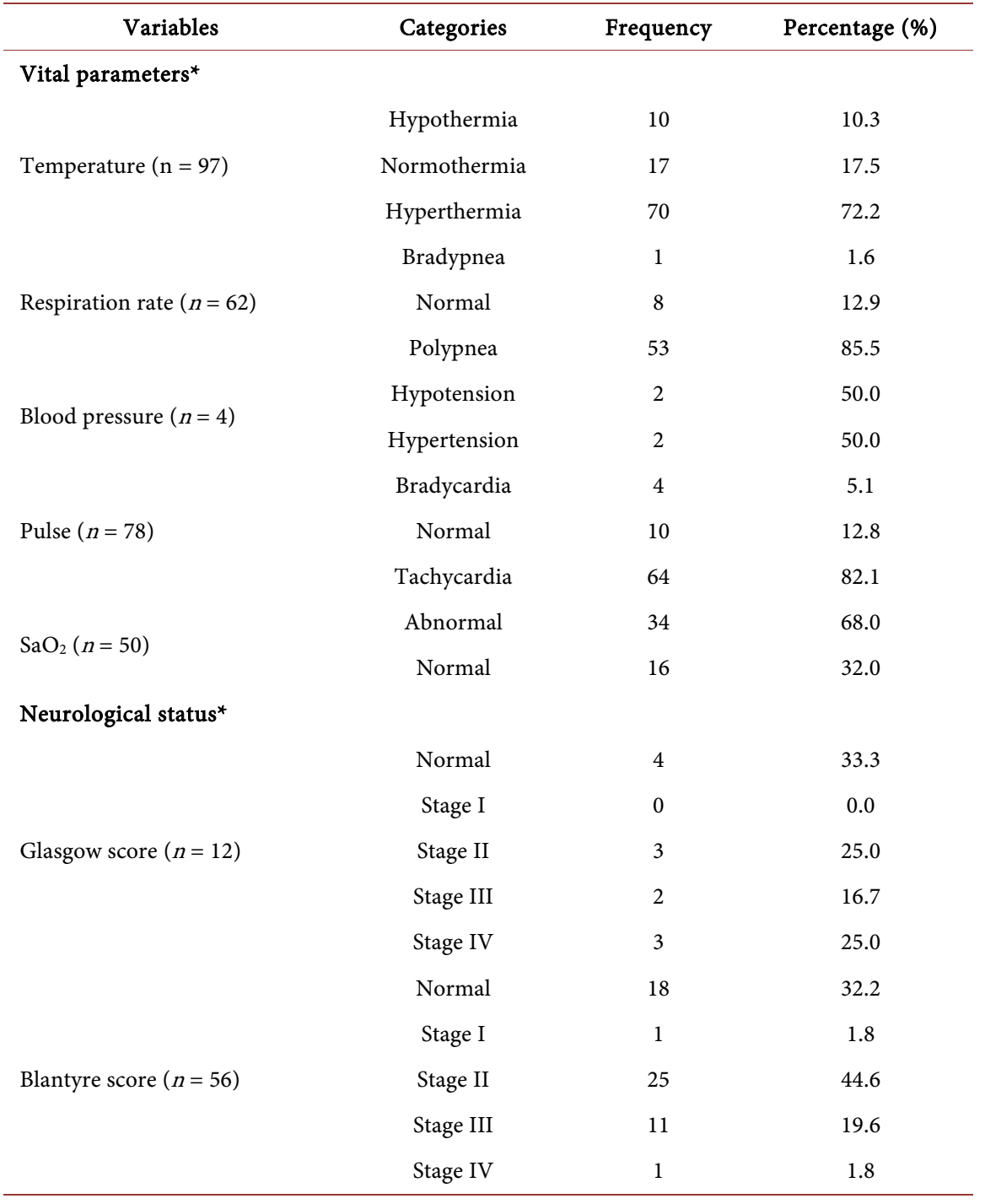

*Missing data were noted for these variables.

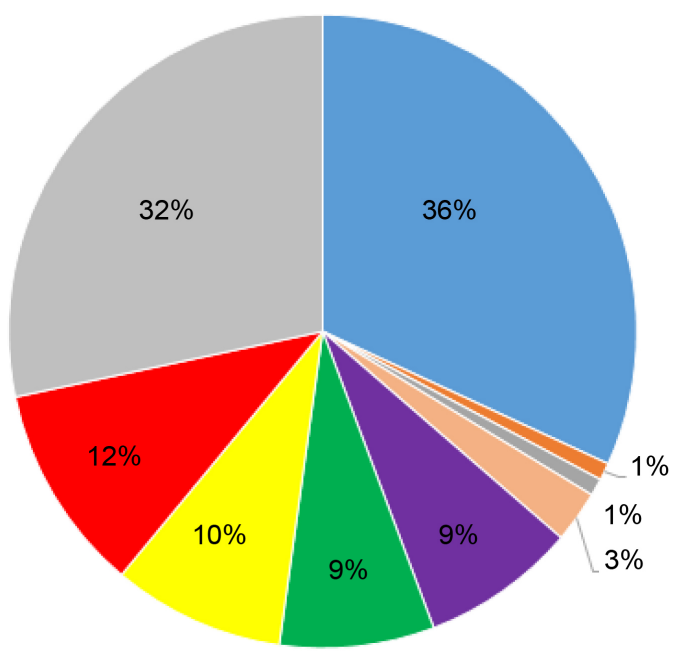

- Unknown

- Respiratory distress

- Severe hypothermia

- Severe malnutrition

- Severe dehydration

- Post operative

Severe anaemia

- Cardiac arrythmia

Decompensated septic shock

Figure 4. Prevalence of different aetiologies of deaths. 
Table 4. Factors associated with mortality.

\begin{tabular}{|c|c|c|c|}
\hline Factors & Categories & OR (95\% CI) & $p$ \\
\hline \multicolumn{4}{|l|}{ Univariate analysis ${ }^{\#}$} \\
\hline \multirow{2}{*}{ Coma/Impaired consciousness } & No & 1 & \\
\hline & Yes & $0.30(0.10-0.88)$ & $0.029^{*}$ \\
\hline \multirow{3}{*}{ Temperature } & Normal & 1 & \\
\hline & Hypothermia & $2.88(0.74-11.14)$ & 0.656 \\
\hline & Hyperthermia & $0.24(0.80-1.33)$ & $0.012^{*}$ \\
\hline \multirow{2}{*}{$\mathrm{SaO}_{2}$} & Normal & 1 & \\
\hline & Abnormal & $2.52(0.71-8.96)$ & 0.151 \\
\hline \multirow{2}{*}{$\mathrm{C}$ reactive protein } & Normal & 1 & \\
\hline & Abnormal & $0.33(0.11-0.95)$ & $0.041^{\star}$ \\
\hline \multirow{2}{*}{ Pneumonia } & No & 1 & \\
\hline & Yes & $3.95(1.42-10.97)$ & $0.008^{*}$ \\
\hline \multirow{2}{*}{ Persistent cough } & No & 1 & \\
\hline & Yes & $3.62(0.81-6.18)$ & 0.092 \\
\hline \multirow{2}{*}{ No medication } & No & 1 & \\
\hline & Yes & $4.50(1.05-9.29)$ & $0.043^{*}$ \\
\hline \multirow{2}{*}{ Antipyretic therapy } & No & 1 & \\
\hline & Yes & $0.28(0.11-0.73)$ & $0.009^{*}$ \\
\hline \multicolumn{4}{|l|}{ Multivariate analysis } \\
\hline Temperature: $\geq 38^{\circ} \mathrm{C}$ & - & $1.32(0.10-18.37)$ & 0.837 \\
\hline $\mathrm{C}$ reactive protein: Abnormal & - & $2.01(0.60-6.67)$ & 0.256 \\
\hline Pneumonia: Yes & - & $2.33(0.66-8.27)$ & 0.189 \\
\hline No medication: Yes & - & $8.63(0.40-187.09)$ & 0.170 \\
\hline Antipyretic therapy: Yes & - & $0.83(0.14-4.78)$ & 0.836 \\
\hline Coma/Impaired consciousness: Yes & - & $6.24(1.15-33.73)$ & $0.034^{*}$ \\
\hline
\end{tabular}

Univariate and multivariate logistic regression test was used to identify associated factors; OR: Odd ratio, 95\% CI: Confidence interval at $95 \%$; ${ }^{*}$ Factors for which $p$-value was below 0.20 in the univariate logistic analysis; ${ }^{*}$ Statistically significant at $p$-value $<0.05$.

\section{Discussion}

We conducted a retrospective, descriptive and analytical study at the DGOPH, a tertiary hospital in the town of Douala, Cameroon. The study was aimed at describing aetiologies and identifying risk factors associated with mortality among children and young adolescents.

\subsection{Sociodemographic Characteristics}

\section{- Trend of Mortality by Year}

Mortality rates were highest during the year 2018 while no deaths were recorded during the year 2015. The hospital started to be functional in 2015, and this is likely the main reason of why no death cases were observed at the hospital. Other factors including the relatively high cost of cares in this hospital and 
its difficult access could also explain this finding.

\section{- Population Distribution by Gender}

Females accounted for more than half of the study population. However, mortality rates were higher in males as compared to females, despite the fact that no statistically significant difference was found. This male predominance among death cases is consistent with findings from previous studies in Togo [16] [17] [18] [19]. Biological factors including genetic, hormonal and anatomical aspects could explain this mortality rate excess observed in males.

\section{- Population Distribution by Age}

Half of children were aged 6 - 12 years old in this study. In contrast, mortality cases were mainly observed in children aged 3 to 5 years. This is in line with previous studies and WHO statistics, and this finding confirms that children under five years still remain the most vulnerable group to morbidity and mortality [12] [13] [20].

\section{- Population Distribution by Origin and Residence}

In our study population, most of the children who died were referred (66\%), and this could be owing to the fact that DGOPH is a reference hospital and receives children coming from health facilities with poor care services. This agrees with results by Ayoola et al. (2005) in Nigeria [3]. Mortality rates were highest in children from populous districts of Douala. This result is not surprising as poverty is an important contributor to mortality risk in all age groups, especially in children. Poverty implies more difficulties to access care services in an easy and rapid way, and increased risk of infectious diseases due to lack/poor sanitation. In addition, low income hinders the usage of health services, and negatively affects the nutrition of children [10].

\section{- Clinical and Paraclinical Presentation of the Deceased Children}

Fever was the principal reason for consultation and associated with mortality. In addition, impaired consciousness was also significantly associated with child mortality. Convulsions are often caused by hyperthermia which can lead to loss or impairment of consciousness (coma). Abnormal CRP levels were associated with reduced mortality risk. This finding is surprising and could be explained by the fact that several conditions including infections can elicit increased CRP levels [21]. To be noted, infections as malaria are a common cause of hyperthermia [22] [23] [24].

\subsection{Mortality and Predictive Factors}

\section{- Mortality according to Diagnosis on Admission}

The present study points out that the main life-threatening conditions are not necessarily those that are responsible for most of mortality cases. Indeed, severe malaria was mainly associated with morbidity while pneumonia was mainly responsible for death cases. This finding is consistent with that by Duboz and colleagues in Congo Brazzaville. In highly malaria endemic areas as Cameroon, children are frequently exposed to infecting bites of the malaria parasites mosquito vectors. They develop an acquired immunity also known as "premonition" 
that protect them from the severe forms of the disease, and thus explains the low share of mortality due to malaria in such areas [25] [26].

- Mortality according to Intra-Hospital Complications and Treatment Received

None of the different intra-hospital complications was found to be associated with mortality. Antipyretic-based therapy was associated with mortality, and this supports the hypothesis that hyperthermia is a natural response to infection, and thus the administration of antibiotics is beneficial to septic patients. This finding is in opposition to that from a previous study that found no reduction in mortality risk in septic patients treated with antibiotics [27].

\section{- Aetiologies of Deaths}

There was no significant correlation between mortality and the different causes of death. More than one third of the children had an unknown circumstance of death, and this is due to not reporting death cause in medical records. This is a common problem seen in health facilities of developing countries, especially those from the public sector. Decompensated septic shock was the second cause of death. This finding points out that infectious diseases are important cause of childhood illnesses and mortality.

\section{- Predictive Factors of Mortality}

As briefly above mentioned, coma/impaired consciousness was predictor of child mortality, and this is consistent with previously conducted studies in Africa and Asia [28] [29] [30] [31] [32].

\subsection{Limitations of the Study}

The main limitation of our study is that it was a single centre study, and this context the findings cannot be extended at the country level. Furthermore, the lack of pathological confirmation of death causes might have affected some of the probable death aetiologies. Finally, socioeconomic status data were not captured in the present study, and thus we were unable to make a yet more detailed analysis of risk factors of child mortality.

\section{Conclusion}

This study outlined that fever was the main reason for consultation, and severe malaria accounted for most of diagnosis on admission. Decompensated septic shock was the main cause of mortality. Factors associated with mortality included coma/impaired consciousness, hyperthermia, pneumonia, antipyretic therapy, and the absence of medication. Most of the deaths in children and young adolescents were due to preventable causes, especially infectious diseases. This suggests that reduction in mortality rate in children and young adolescents can be achieved by efficient management of these underlying causes.

\section{Acknowledgements}

To all the staff of the Pediatrics Department of the Douala Gynaeco-Obstetric 
and Pediatric Hospital, Douala, Cameroon.

\section{Authors' Contribution}

- Conception and design: Daniele Kedy Koum, Calixte Ida Penda, Christiana Mpongo Moukongo, Emile Telesphore Mboudou, Paul Koki Ndombo.

- Acquisition of data: Christiana Mpongo Moukongo, Daniele Kedy Koum, Diomede Noukeu, Dominique Enyama.

- Analysis and interpretation: Daniele Kedy Koum, Loick Pradel Kojom Foko, Dominique Enyama, Mbono Rhita, Laurent Mireille Endale.

- Drafting/Revising the manuscript: Daniele Kedy Koum, Laurent Mireille Endale Henri Essome, Loick Pradel Kojom Foko, Cecile Okalla Ebongue, Charlotte Eposse, Patricia Epée Eboumbou.

- Final approval of the version: all the authors.

- Agreement to be accountable for all aspects of the work: Daniele Kedy Koum, Emile Telesphore Mboudou, Paul Koki Ndombo.

All the authors of the manuscript have read and agreed to its content and are accountable for all aspects of the accuracy and integrity of the manuscript.

\section{Conflicts of Interest}

The authors declare no conflicts of interest regarding the publication of this paper.

\section{References}

[1] American Medical Association (1997) Encyclopédie médicale de la famille. Vol. 1151, Larousse-Bordas, Larousse, Italie, 663 p.

[2] World Health Organization (2018) Global Health Estimates 2016: Deaths by Cause, Age, Sex, by Country and by Region, 2000-2016. World Health Organization, Geneva.

https://www.who.int/data/gho/data/themes/mortality-and-global-health-estimates

[3] Ayoola, O.O., Orimadegun, A.E., Akinsola, A.K. and Osinusi, K. (2005) A Five-Year Review of Childhood Mortality at the University College Hospital, Ibadan. West African Journal of Medicine, 24, 175-179. https://doi.org/10.4314/wajm.v24i2.28192

[4] Black, R.E., Morris, S.S. and Bryce, J. (2003) Where and Why Are 10 Million Children Dying Every Year? Lancet, 361, 2226-2234. https://doi.org/10.1016/S0140-6736(03)13779-8

[5] Orne-Gliemann, J., Perez, F., Leroy, V., Newell, M.L. and Dabis, F. (2003) A Decade of Child Health in Developing Countries. Sante, 13, 69-75.

[6] Bawaskar, H.S. (2003) The World's Forgotten Children. Lancet, 361, 1224-1225. https://doi.org/10.1016/S0140-6736(03)12931-5

[7] UNICEF (United Nations International Children's Emergency Fund) (2003) Statistical Tables: Health Official Summary of the State of the World's Children. United Nations International Children's Emergency Fund, Geneva, Switzerland. https://www.unicef.org

[8] Asley, J.S. (1972) Present State of Statistics from Hospital In-Patient Data and Their Uses. British Journal of Preventive and Social Medicine, 26, 135-147. 
https://doi.org/10.1136/jech.26.3.135

[9] Kaine, W. and Okolie, J. (1975) A Review of the Causes of Hospitalisation as a Guide to the Pattern of the Diseases in Eastern Nigeria. Nigerian Medical Journal, 7, 205.

[10] Niyeha, D., Malamsha, D., Mpembeni, R., Charwe, D., Epimark, S., Malima, K., Aveika, A., Aung, T., Hazel, E., Tam, Y. and Heidkamp, R. (2018) Explaining Progress towards Millennium Development Goal 4 for Child Survival in Tanzania. Journal of Global Health, 8, Article ID: 021201.

[11] Najat, L. (2015) Epidémiologie de la mortalité de l'enfant a l'hôpital mère-enfant: Centre Hospitalier Universitaire de Mohammed de Marrakech: Etude rétrospective sur 5 ans. Thèse de Doctorat, Faculté de Médecine et de Pharmacie-Marrakech, Maroc, $81 \mathrm{p}$.

http://wd.fmpm.uca.ma/biblio/theses/annee-htm/FT/2015/these147-15.pdf

[12] Organisation des Nations Unies (2014) Objectif du Millénaire pour le développement: Rapport 2014. http://www.un.org

[13] World Health Organization (2016) Global Strategy for Woman's, Children's and Adolescent's Health 2016-2030. The World Health Organisation, Geneva.

https://www.who.int/data/maternal-newborn-child-adolescent-ageing/global-strate gy-data

[14] United Nations (2020) Sustainable Development. https://sustainabledevelopment.un.org/

[15] Nsagha, S.D., Assob, N.J.C., Kamga, F.H.L., Njunda, L.A., Nde, P.F., Mpei, E. and NNjouendou, A.J.N.N. (2014) Facteurs Influençant la mortalité au service de pédiatrie de l'hôpital Régional de Nkongsamba au Cameroun. African Journal of Integrated Health, 3, 38-45.

[16] World Health Organization (2001) Maternal Mortality in 1995: Estimates Developed by WHO, UNICEF, UNFPA. World Health Organization, Geneva. https://apps.who.int/iris/handle/10665/66837

[17] Sawyer, C.C. (2012) Child Mortality Estimation: Estimating Sex Differences in Childhood Mortality since the 1970s. PLoS Medicine, 9, e1001287.

https://doi.org/10.1371/journal.pmed.1001287

[18] Tanagan, K., Moussa, T., Atego, S., Agbérè, A.D., Kessie, K. and Assimadi, K. (1995) Analyse de la mortalité hospitalière dans deux services de pédiatrie du Togo (Lomé et Kra) de 1987-1989. Médecine d' Afrique Noire, 25, 111-117.

[19] Gouna, A.M.S. (1996) Analyse de la mortalité neonatale dans les services de pédiatrie du CHU (Lomé) et du CHR d'Atakpamé en 1981-1982 et 1991-1992. Mémoire EAM-UB. No. 121, Université de Lomé, Lomé.

[20] Alate, A. (1991) La mortalité et morbidité des enfants de 5 à 14 ans à l'hôpital général de Brazzaville du $1^{\mathrm{er}}$ Janvier au 31 Décembre 1987. Médecine d' Afrique Noire, 38, 641-648.

[21] Agbérè, A.D., Baeta, S., Balaka, B. and Douti, Y. (1998) La mortalité néonatale à l'hôpital d'enfants de Tantigou. Dapaong (Nord-Togo) en 1984-1985 et 1994-1995. Bulletin de la Société de Pathologie Exotique, 91, 315-317.

[22] Nneka, C.O., Chukwuemeka, N.O. and Chioma, A.O. (2018) Pattern and Outcomes of Paediatric Medical Admission at the Living Ward Mission Hospital. Aba. South East Nigeria. Pan African Medical Journal, 30, Article No. 202.

https://doi.org/10.11604/pamj.2018.30.202.15966

[23] Landry, A., Docherty, P., Ouellette, S. and Cartier, L.J. (2017) Official Publication of 
the College of Family Physicians of Canada. Causes and Outcomes of Markedly Elevated C-Reactive Protein Levels. Canadian Family Physician, 63, e316-e323.

[24] Muluneh, D., Shimelis, D. and Benti, D. (2007) Analysis of Admission to the Pediatric Emergency Ward of Tikur Anbessa Hospital in Addis Ababa, Ethiopia. Ethiopian Journal of Health Development, 21, 48-52. https://doi.org/10.4314/ejhd.v21i1.10031

[25] Shaeem, M.H., Sana, T., Nasiruddin, M. and Ahm, K. (2012) Disease Profile and Death Pattern among Children Admitted in a Medical College Hospital. Bangladesh Journal of Child Health, 36, 66-70.

[26] Gordon D.M., Frenning, S., Heather, R.D. and Kokeb, M. (2013) Prevalence and Burden of Diseases Presenting to a General Pediatric ward in Gonder, Ethiopia. Journal of Tropical Pediatrics, 5, 350-357. https://doi.org/10.1093/tropej/fmt031

[27] Maitland, K., Kiguli, S., Opoka, R.O., Engoru, C., Olupot-Olupot, P., Akech, S.O., Nyeko, R., Mtove, G., Reyburn, H., Lang, T., Brent, B., Evans., J.A., Tibenderana, J.K., Crawley, J., Russelln E.C., Levin, M., Babiker, A.G., Gibb, D.M. and FEAST Trial Group (2013) Mortality after Fluid Bolus in African Children with Severe Infection. New England Journal of Medicine, 364, 2483-2495.

https://doi.org/10.1056/NEJMoa1101549

[28] Djadou, K.E., Segbedji, A., Azoumah, K.D., Koffi, S., Atakouma, D.Y., Agbere, A.D. and Bakonde B. (2013) Mortalité hospitalière des enfants agés moins de 5 ans au CHR-Tsevie (Togo), de 2007 à 2011. Journal de la Recherche Scientifique de P Université de Lomé, 15, 137-145.

[29] Ye, S., Xu, D., Zhang, C., Li, M. and Zhang, Y. (2017) Effect of Antipyretic Therapy on Mortality in Critically III Patients with Sepsis Receiving Mechanical Ventilation Treatment. Canadian Respiratory Journal, 2017, Article ID: 3087505. https://doi.org/10.1155/2017/3087505

[30] Ahmad, I., Ahmed, K., Ahmad Gattoo, I., Younous Mir, M., Maqbool, M. and Baba, A.R. (2015) Non-Traumatic Coma in Children: A Prospective Observational Study. International Journal of Contemporary Pediatrics, 2, 77-84. https://doi.org/10.5455/2349-3291.ijcp20150504

[31] Arun, B., Singhi, S.C., Pratibha, D.S., Khandelwal, N. and Rmesh, S. (2005) Non Traumatic Coma. Indian Journal of Pediatrics, 72, 467-473. https://doi.org/10.1007/BF02724422

[32] Ogunmekan, A.O. (1983) Non Traumatic Coma in Childhood: Etiology, Clinical Features, Morbidity, Prognosis and Mortality. Journal of Tropical Pediatrics, 29, 230-232. https://doi.org/10.1093/tropej/29.4.230 


\section{Supplementary File 1. Questionnaire Form}

$\mathrm{N}^{0}$ Sheet $\mathrm{N}^{0}$ Registered of death

Date of inclusion: / 2019

I. IDENTIFICATION

1) Name \& surname:

2) Date of birth (DD/MM/YYYY):

1

I

3) Age (in month or in year):

4) Date of admission: / $\ldots . . .$.

5) Time of admission:

6) Date of death . $/ \ldots \ldots . . . . . \ldots \ldots$

7) Time of death:

8) Delay of death from admission (in days or hours):

9) Month of death: $\square$ Jan, $\square$ Feb, $\square$ Mar, $\square$ Apr, $\square$ May, $\square$ Jun, $\square$ Jul, $\square$ Aug, $\square$ Sep, $\square$ Oct, $\square$ Nov, $\square$ Dec

10) Age groups of death: 1 month - 2 years (toddler), 3 years - 5 years (infant), 6 years - 12 years (child) and 13 years - 15 years (teenager)

11) Gender: $\square \mathrm{M} \quad \square \mathrm{F}$

12) Origin: $\square$ Home $\square$ Referred

II. REASONS FOR CONSULTATION

1) Fever

$\square$ Yes $\square$ No

2) Headache

$\square$ Yes $\square$ No

3) Cough

$\square$ Yes $\square$ No

4) Chest pain

$\square$ Yes $\square$ No

5) Abdominal pain

$\square$ Yes $\square$ No

6) Fatigue

$\square$ Yes $\square$ No

7) Pallor

$\square$ Yes $\square$ No

8) Respiratory distress

$\square$ Yes $\square$ No

9) Diarrhea

$\square$ Yes $\square$ No

10) Vomiting

$\square$ Yes $\square$ No

11) Edema

$\square$ Yes $\square$ No

12) Convulsion

$\square$ Yes $\square$ No

13) Coma/ impaired consciousness

$\square$ Yes $\square$ No

14) Trauma

$\square$ Yes $\square$ No

15) Congenital malformation

$\square$ Yes $\square$ No

16) Other reasons for consultation

$\square$ Yes $\square$ No

17) If Yes, specify.

III. MEDICAL HISTORY

18) HIV

$\square$ Yes $\square$ No

19) Hemophilia

$\square$ Yes $\square$ No

20) EPI

$\square$ Yes $\square$ No

21) Out EPI

$\square$ Yes $\square$ No

22) Others

IV. INPUT PARAMETERS 
1) Vital parameters:

Temperature $\left({ }^{\circ} \mathrm{C}\right)$

Pulse(pulse/min)

Blood pressure (mmHg) ..Respiratory rate (breath/min)

Glasgow (15) Blantyre (5) $\mathrm{SaO}_{2}(\%)$

2) Anthropometric parameters:

Weight (Kg). $\operatorname{Height}(\mathrm{m})$

head circumference $(\mathrm{cm})$

MUAC $(\mathrm{cm})$.... $\mathrm{W} / \mathrm{H}$

V. INPUT DIAGNOSTIC (reasons for hospitalization)

1) Severe malaria

$\square$ Yes $\square$ No

2) Severe malnutrition

$\square$ Yes $\square$ No

3) Severe dehydration

$\square$ Yes $\square$ No

4) Meningitis

$\square$ Yes $\square$ No

5) Acute abdomen

$\square$ Yes $\square$ No

6) Pneumonia

$\square$ Yes $\square$ No

7) Sickle cell anemia

$\square$ Yes $\square$ No

8) Respiratory tract infection

$\square$ Yes $\square$ No

9) Urinary tract infection

$\square$ Yes $\square$ No

10) Intracranial hemorrhage

$\square$ Yes $\square$ No

11) Tetanus

$\square$ Yes $\square$ No

12) Septicemia

$\square$ Yes $\square$ No

13) Caustic ingestion

$\square$ Yes $\square$ No

14) Others

$\square$ Yes $\square$ No

15) If yes, precise.

VI. LABORATORY ANALYSIS AND MEDICAL IMAGING
1) Blood glucose level:
$\square$ Yes $\square$ No

2) If yes, highest blood glucose level during hospitalization:

3) CRP:

$\square$ Yes $\square$ No

4) If yes, highest CRP level during hospitalization: ... $\mathrm{mg} / \mathrm{L}$

5) Full blood count:

$\square$ Yes $\square$ No

6) If yes, lowest hemoglobin level during hospitalization: $. . \mathrm{g} / \mathrm{dL}$

7) Tick drop:

$\square$ Yes $\square$ No

8) If yes, tick drop:

$\square$ Positive $\square$ Negative

9) Serum electrolytes:

$\square$ Yes $\square$ No

10) If yes, abnormalities:

$\square$ Yes $\square$ No

11) HIV test:

$\square$ Yes $\square$ No

12) If yes, test:

$\square$ Positive $\square$ Negative

13) Cerebral spinal fluid analyzed:

$\square$ Yes $\square$ No

14) If yes, abnormalities

$\square$ Yes $\square$ No

15) Dipstick:

$\square$ Yes $\square$ No

16) If yes, abnormalities

$\square$ Yes $\square$ No

17) Abdominal scan:

$\square$ Yes $\square$ No

18) If yes, abnormalities

$\square$ Yes $\square$ No

19) EEG:

$\square$ Yes $\square$ No 
20) If yes, abnormalities:

21) Cerebral scan:

22) If yes, abnormalities:

23) TFE:

24) If yes, abnormalities:

25) Chest X-ray:

26) If yes, abnormalities:

27) Others analysis

28) If yes, details

VII. EVOLUTION (during hospitalization)

-Parameters:

A. Vital parameters:

Temperature $\left({ }^{\circ} \mathrm{C}\right)$ Pulse (pulse/min)

Blood pressure(mmHg) Respiratory rate (breath/min)

Glasgow (15)

B. Anthropometric parameters:

Weight $(\mathrm{Kg})$ MUAC (cm) Height $(\mathrm{m})$ $\square$ Yes $\square \mathrm{No}$

$\square$ Yes $\square$ No

$\square$ Yes $\square$ No

$\square$ Yes $\square$ No

$\square$ Yes $\square$ No

$\square$ Yes $\square$ No

$\square$ Yes $\square$ No

$\square$ Yes $\square$ No

Complains:
1) Persistent fever
$\square$ Yes $\square$ No
2) Persistent cough
$\square$ Yes $\square$ No
3) Persistent edema
$\square$ Yes $\square$ No
4) Persistent headache
$\square$ Yes $\square$ No
5) Persistent abdominal pain
$\square$ Yes $\square$ No
6) Persistent fatigue
$\square$ Yes $\square$ No
7) Persistent pallor
$\square$ Yes $\square$ No
8) Persistent vomiting
$\square$ Yes $\square$ No
9) Persistent diarrhea
$\square$ Yes $\square$ No
10) Persistent seizure
$\square$ Yes $\square$ No
11) Another significant event
$\square$ Yes $\square$ No
12) If yes, specify
VII. TREATMENT
a.) Non-medicated means
1) Rehydration
$\square$ Yes $\quad \square$ No
2) Blood transfusion
$\square$ Yes
$\square \mathrm{No}$
3) Oxygenation
$\square$ Yes
$\square$ No
4) Reanimation
$\square$ Yes
$\square$ No
5) Nursing
$\square$ Yes
$\square \mathrm{No}$
6) Monitoring
$\square$ Yes
$\square$ No
b.) Therapeutics used
7) Antibiotic
$\square$ Yes $\quad \square$ No
8) Antipyretic
$\square$ Yes
$\square$ No
9) Anti-malarial drugs
$\square$ Yes
$\square$ No
10) Anti-epileptic drugs
$\square$ Yes
$\square$ No 


\begin{tabular}{|c|c|c|}
\hline 11) Surgery & $\square$ Yes & $\square$ No \\
\hline 12) No medication & $\square$ Yes & $\square$ No \\
\hline 13) If yes, why...... & & \\
\hline 14) Others & $\square$ Yes & $\square$ No \\
\hline
\end{tabular}

VIII. ETIOLOGIES OF DEATH

1) Severe anemia $\quad \square$ Yes $\square$ No

2) Severe dehydration $\square$ Yes $\square$ No

3) Decompensated septic shock $\square$ Yes $\square$ No

4) Severe malnutrition $\square$ Yes $\square$ No

5) Intracranial hemorrhage $\square$ Yes $\square$ No

6) Cardiac arrhythmia $\square$ Yes $\square$ No

7) Post-operative $\square$ Yes $\square$ No

8) Post blood transfusion $\square$ Yes $\square$ No

9) Cause of unknown dead $\square$ Yes $\square$ No

10) Other causes of death $\square$ Yes $\square$ No

If Yes, specify: 